\title{
A PILOT STUDY OF SMALL BUSINESS'S PERCEPTION OF VENDOR PROVIDED SERVICES: ARE THESE ASSOCIATED WITH SMALL BUSINESS IT EDUCATIONAL REQUIREMENTS?
}

\author{
R.C. MacGregor ${ }^{1}$ D.J. Bunker ${ }^{1}$ J.K. Pierson ${ }^{2}$ K.A. Forcht ${ }^{2}$ \\ ${ }^{1}$ Department of Business Systems \\ University of Wollongong \\ Northfields Avenue, Wollongong, Australia 2522 \\ ${ }^{2}$ Department of Information and Decision Sciences \\ James Madison University \\ Harrisonburg Virginia 22807 USA
}

\begin{abstract}
Despite the extensive use of microcomputers in the small business environment, little research has been applied to the training needs of those small businesses. This study examines the computer related training needs of 131 small businesses and the factors which appear to impinge upon those needs. In particular the paper examines whether satisfaction with vendor provided services (both pre and post sales) are associated specific educational requirements in small business. The results suggest that there a need for the development of a university/college IT training program directed specifically towards small business. These programs should avoid the more technical aspects of IT and concentrate on areas which involve the analysis and use of software in the small business. The results further show that a number of vendor provided services appear to be associated with the rating of importance of potential curricular inclusions in IT training programs.
\end{abstract}

\section{INTRODUCTION}

Since the microcomputer became readily available in the early 1980 's, more and more small firms have adopted them in their day-to-day operations. Initially, most small businesses acquired computer technology for the purposes of accounting (Baker 1987, Heikkila, Saarinan \& Saaksjarvi 1991). More recently, computer technology has been acquired for a variety of uses (Raymond \& Paré 1992, Raymond 1990, Raymond \& Bergeron 1992). With increase in sophistication of information systems used in small business, there has been a growing need to provide adequate training for personnel (Cragg \& Zinatelli 1995).

Originally training was minimal, usually being provided by the vendor from whom the technology was purchased. Today, however, more and more training is provided by service organisations and, in some cases, universities and colleges. A number of reasons have been suggested. Raymond et al (1993) suggest that the use of technology by small business tends to affect the structure of the business, often resulting in a more complex organisation, with the increase of technology use. Chan \& Huff (1993) suggest that technology allows the organisation to focus on strategic decisions rather than simply maintaining the operational status quo. With this change of emphasis, there is a requirement to examine training curricula which addressed the needs of the small business client.

When considering curriculum design, Nelson (1991) suggests that a curriculum which merely addresses the technical issues only provides half the requisite knowledge and skills necessary to adequately adopt and maintain information technology in an organisation. This is supported in the literature by the many studies which point to the problem incurred when organisational issues are not adequately considered at the inception of technology (Turner \& Karasek 1984, MacGregor \& Clarke 1988, Raymond 1988, Sharp \& Lewis 1992, Kahn \& Robertson 1992, Williams 1992, Bergeron et al 1992, Hedberg \& Harper 1992).

A number of studies (Wattenberger \& Scaggs 1979, Rislov 1979, Hansen 1985, El-Khawas 1985, Dawkins 1988, Beeson et al 1992) have suggested that in order to include organisational issues in curriculum design, it is necessary to involve employer groups in the development of university/college IT training programs. While many of these studies focus on larger businesses, recent studies (Neergaard 1992, Holzinger \& Hotch 1993, MacGregor \& Cocks 1994, DelVecchio 1994) have suggested that there is no less a need to involve employer groups at the small business level.

A number of factors have been found to impinge upon both the use of computer technology as well as the training requirements deemed necessary in the small business environment. Some of these factors may be termed 'intrinsic', ie. they are part of the structure and function of the firm. These would include the size of the firm, the level of management involvement, the level of skill of the workforce (Cragg \& Zinatelli 1995, MacGregor \& Bunker 1995). Other factors such as complexity of the software acquired, changes to structure of the workplace after the implementation of IT and criteria for determination of success are more 'extrinsic' factors which impinge upon use of ITas well as training requirements.

This paper begins by briefly considering the findings of several studies examining the acquisition and subsequent use of computer technology in the medical profession which provides the research background for the study. The nature of small business is briefly considered. The paper then examines small business IT curricula needs. Finally, it is hypothesised that, in line with the background study findings, the level of satisfaction with pre- 
installation vendor service will affect those curricular inclusions deemed most important by the small business community, while the level of satisfaction with vendor post-installation services will affect those curricular inclusions less important to the small business community.

\section{RESEARCH BACKGROUND}

Several studies were carried out in Australia examining the various branches of the medical profession and their use and training need following the acquisition of computer technology (MacGregor \& Cocks 1994, MacGregor et al 1997). These studies found that amongst other factors associated with use and training requirements of IT was the level of satisfaction with vendor services. The study found that the level of satisfaction / dissatisfaction with those vendor services normally provided prior to purchase and installation was strongly associated with the rating of curricular inclusions deemed important inclusions in training programs. These pre-installation services included delivery of equipment, vendor supplied information concerning the suitability of equipment and software to the business as well as overall equipment suitability.

By comparison, the study found that no such association was evidenced when post-installation services were examined. These post installation services included training, vendor supplied manuals and documentation as well as vendor after sales service. Indeed, the study found that the level of satisfaction / dissatisfaction with vendor post-installation service was only associated with curricular inclusions deemed less important in a training program.

Based on the finding within the medical profession, this study aims to determine whether these associations (satisfaction with vendor services \& rating of importance of potential curricular inclusions in an IT training program) are unique to the medical profession or whether they apply to small business in general.

\section{THE NATURE OF SMALL BUSINESS}

There have been many studies, both in terms of research initiatives as well as governmental studies on the nature of small business. Many of these studies have opted for the approach which identifies the differences of small to large business and it is this approach which best summarises the nature of small business. Studies by Brigham \& Smith (1967), Walker (1975), Delone (1988) found that small businesses are more risky than their larger counterparts. Rotch (1987) found the amount of record keeping is minimal compared to larger businesses. Reynolds et al (1994), in an extensive study, suggest that, among other factors, small businesses tended to be centralised with informal and inadequate planning and control, concentrated more on product than customers and used limited process or product technology.

This is accentuated when computer technology is introduced into the small business environment. Studies (Cragg \& King 1993, Holzinger \& Hotch 1993, Chen 1993, DelVecchio 1994) showed that small businesses lacked the relevant technical expertise to identify and acquire computer technology, very often relying on vendor/consultant groups to perform these tasks. Indeed, one of the more pertinent studies examining this phenomenon was carried out in Singapore (see Yap et al 1992). Among other findings, the study showed that where larger businesses used a resident IT department, smaller businesses viewed the vendor/consultant as a surrogate of that IT department. The study showed that the level and type of service provided by the vendor very often permeated all facets of continued use with the technology including upgrading decisions, company structuring around the newly acquired technology, level of use of the technology. This has been supported in subsequent studies (Cragg \& Zinatelli 1995, MacGregor \& Bunker 1995). In all these studies the vendor was a small business consisting of a sales force with some technical support. Most were retailers of technology rather than branches of manufacturers.

\section{BACKGROUND TO THE RESEARCH}

The definition of what constitutes a small business varies both across research initiatives as well as governmental guidelines. A number of researchers (Delone 1988, Chen 1993) have avoided these questions by using governmental guidelines and employing mailing lists prepared by these government agencies. The current study has adopted a similar approach by developing a mailing list through the Small Business component of the Illawarra Chamber of Commerce Directory, known as the Illawarra Business Directory. The geographic area covered by this directory includes southern suburbs of Sydney, as well as the cities of Nowra and Wollongong (a population of approximately half a million).

As with the definition of small business, decisions concerning inclusions in IT training programs offered through university/colleges vary widely. Two internationally regarded models have been provided by the ACM and the DPMA groups. Lo (1991) suggested that in order to fully examine all possible curricular inclusions a composite subset of those provided by ACM and DPMA needed to be established. Lo's study arrived at 51 subjects. 
The current study began with the set suggested by Lo. These were examined in the light of small business needs. A number were discarded, being considered more relevant to computing professionals than small business. These included areas such as Data Communications, Advanced Programming and Algorithm Development, Expert Systems, Human Computer Interaction. Those that remained were further analysed for content to determine whether they could be 'collapsed' into a smaller group. This approach is in line with the views expressed by Seeborg \& Ma (1989) who state that when non-computing groups were considered, the potential offerings should be significantly reduced. As such, Lo's original 51 subjects were reduced to 15 (see Table 1).

Table 1

Curriculum Subject Groups

Subjects

Structure and function of computer hardware

Programming

Database/Spreadsheets

Business Analysis

Information Analysis

Office Automation

Business Accounting Systems

Computer Evaluation Techniques

Accountancy

Finance

Marketing

Business Law

Statistics

Management Principles

Interpersonal Skills

\section{Brief Description}

study of the major components of the microcomputer

problem solving and program development

the use of databases and spreadsheets in common business problems

analysis of the major functions and data in the business

data modeling techniques

integration of the microcomputer into the office

design and use of accounting software

techniques for testing and comparing potential hardware and software purchase options

introductory principles of accounting

introduction to corporate valuations and financial markets

market segments, buyer behaviour etc.

partnerships, liabilities, contracts etc.

descriptive and inferential statistics

goal determination, implementation etc.

verbal, written, formal and informal communication

In line with the studies carried out by MacGregor \& Cocks (1994) two hypotheses were tested. For clarity these will be phrased in the affirmative, rather than the null.

$\mathrm{H}_{1} \quad$ The level of satisfaction with vendor pre-installation service (delivery of equipment, vendor supplied information, equipment suitability) is positively associated with the perception of importance of those curricular inclusions deemed important. In other words, high levels of satisfaction with vendor services will be accompanied by a higher rating of those curricular inclusions deemed most important. 
$\mathrm{H}_{2} \quad$ The level of satisfaction with vendor post-installation service (Manuals, training, after sales service) is positively associated with the perception of importance of those curricular inclusions deemed less important. In other words, high level of satisfaction with vendor post-installation service will not be accompanied with a higher rating of those curricular inclusions deemed most important but will be accompanied with a higher rating of those curricular inclusions deemed less important.

It should be noted that the determination of which curricular inclusions are most important and which are less important are based on the responses to the questionnaire. In line with previous studies (Seeborg \& Ma 1989, Lo 1991, Ang \& Lo 1991, Ang 1992), only the top six rated curricular inclusions will be considered most important. All others will be considered less important.

\section{METHOD}

As already noted, a mailing list was developed from a government supplied list known as the Illawarra Business Directory. The definition used within this document for small business was that the company had 50 or less employees and was not a subsidiary of any other firm. As the study was examining the association between vendor supplied services and the rating of curricular inclusions in an IT training program, vendor companies fitting the profile of small business were removed from the mailing list.

A questionnaire was developed to be sent to small business managers. Respondents were asked to rate the curricular inclusion areas (see Table 1) in terms of their importance (1 not very important - 5 very important) as an inclusion in a college/university provided IT training program directed towards small business. Additionally respondents were asked to rate their perception of vendor services ( 1 very poor - 5 very good) in the following:

- delivery and installation of computer equipment

- availability of information concerning computer technology

- satisfaction with equipment and software

- after sales service

- computer systems training

- computer systems documentation

\section{ANALYSIS OF RESULTS}

A total of 600 questionnaires were distributed. Responses were obtained from 131 businesses representing a $21.8 \%$ response. This is substantially higher than the $10 \%$ and $7 \%$ responses achieved by MacGregor \& Cocks in their examination of the medical profession.

$58 \%$ of respondents indicated that they had previously undertaken some form of college/university training in their particular field. Less than $20 \%$ had undertaken any college/university based IT training.

Of particular interest was the fact that all respondents indicated the regular use of $I T$ in their day-to-day business, with only $7 \%$ of respondents indicating they had been using computer technology for less than a year.

Prior to examining the hypotheses, it was necessary to gain an overall opinion as to the general interest in college/university based IT program directed to small business. As such, the following approach was adopted. If any one of the 15 curricular inclusion areas (see Table 1) was rated 5 (very important) by a respondent, the respondent was categorised as seeing the development of a college/university IT training program for small business as very important. If no curricular inclusions was rated at 5 but at least one was rated at 4 (important), the respondent was categorised as seeing some importance to the development of such a program. All other respondents were categorised as seeing no importance in such a program. Table 2 provides the responses.

Table 2

The importance of developing a college/university based IT training program for small business

$\begin{array}{lll}\text { Very Important } & \text { (at least one curricular inclusion rated 5) } & 109 \\ \text { Important } & \text { (at least one curricular inclusion rated 4) } & 12 \\ \text { Not Important } & & 10\end{array}$

The results in Table 2 suggest that there is a perception by the small business managers who responded to the survey of the importance of a university/college based IT training program specifically directed to small business. $83 \%$ of the respondents considered the development of a training program to be important, with a further $9 \%$ giving some support to such a development. While only $58 \%$ of the respondents indicated some form 
of university/college education, the results are almost identical to those carried out on the medical profession (MacGregor \& Cocks 1994). In those studies, 84.5\% of respondents indicated their support for a university/college based IT training course directed towards their specific needs, with a further $10.4 \%$ seeing some importance to the development.

Respondents were asked to rate vendor performance (on a scale 1 - very poor to 5 - very good) across six categories. These were:

- delivery and installation of computer equipment

- availability of information concerning computer technology

- satisfaction with equipment and software

- after sales service

- computer systems training

- computer systems documentation

Table 3 indicates the overall responses.

Table 3

Service

- delivery and installation of computer equipment

- availability of information concerning computer technology

- satisfaction with equipment and software

- after sales service

- computer systems training

- computer systems documentation
Table 3 Services by Small Business managers Rating

$\begin{array}{cllll}\begin{array}{c}\mathbf{1} \\ \text { Very Poor }\end{array} & \mathbf{2} & \mathbf{3} & \mathbf{4} & \mathbf{5} \\ 9 & 16 & 31 & 50 & 25 \\ \text { Very Good } & 25 \\ 6 & 25 & 44 & 32 & 24 \\ & & & & \\ 7 & 11 & 34 & 51 & 28 \\ 13 & 22 & 49 & 28 & 19 \\ 28 & 26 & 51 & 17 & 9 \\ 26 & 24 & 42 & 24 & 15\end{array}$

A study carried out by MacGregor \& Cocks (1994) on the computer usage of the Australian Veterinary profession showed that by far the greatest dissatisfaction with vendor services appeared to be in the areas of vendor documentation and manuals, vendor after sales problem rectification and vendor training. An examination of Table 4 would suggest that this trend is not isolated to the area of veterinary software but appears to affect all areas of small business. While $63 \%$ of small business respondents rated the equipment as above average, only $19.6 \%$ rated the training in the same manner. An examination of the figures pertaining to manuals and documentation, as well as after sales problem rectification, show that vendor after sales service is, for the most part not rated highly. Only $28 \%$ of the respondents considered the manuals and documentation above average, while $37 \%$ rated problem rectification by the vendor as above average. Indeed, it would seem that in all areas of after sales service (changes to system, training, documentation and problem rectification) vendor support and services were significantly less than those areas which might be designated 'pre-sales support'.

Respondents were asked to rate the 15 curricular inclusions in terms of their importance for a university/college IT training course for small business. Table 4 shows the means and ranking of responses. 
Table 4

Relative Importance of each of the curricular inclusions

$\begin{array}{lll}\text { Topic } & \text { mean } & \text { rank } \\ \text { Structfunct of hardware } & 3.16 & \\ \text { Programming } & 3.09 & 10.5 \\ \text { Database/S'sheet } & 4.18 & 2 \\ \text { Business Analysis } & 4.04 & 4 \\ \text { Info. Analysis } & 4.08 & 3 \\ \text { Office Autom. } & 3.75 & 6 \\ \text { Bus/Acc't Systs } & 4.28 & 1 \\ \text { Eval. Techniques } & 3.39 & 8 \\ \text { Accounting } & 4.01 & 5 \\ \text { Finance } & 3.65 & 7 \\ \text { Marketing } & 3.10 & 12 \\ \text { Business Law } & 2.66 & 15 \\ \text { Statistics } & 2.99 & 14 \\ \text { Mgt Principles } & 3.16 & 10.5 \\ \text { Interpersonal Skills } & 3.19 & 9\end{array}$

The results in Table 4 show that the most preferred inclusions (deemed to be the top six) in a university/college IT training programs for small business are: Business and Accounting Systems, Database and Spreadsheets, Information Analysis, Business Analysis, Accounting, and Office Automation. It is interesting to note that a previous study of the medical profession (MacGregor \& Cocks 1994) showed that five of the six were also considered very important. Indeed, the only difference between the two respondent groups was that the medical profession indicated a need for Marketing in preference to Office Automation.

The results in Table 4 highlight several other important issues. Firstly, there appears to be a perception by small business respondents of the need to fully understand the nature of their business and the data that business utilises. This is borne out in the high ratings of Business Analysis and Information Analysis. Secondly, there is a perception that knowledge of hardware and software is of less importance to the business than the understanding of the proper use of the software. Finally, there appears a perception that in order to use database, spreadsheets and accounting software correctly, there is a need to complete some study in the area of Accounting.

A series of chi-square tests were applied to the data to determine whether the ratings of the curricular inclusions were associated with the ratings of the six vendor services. Table 5 indicates those curricular inclusions whose rating was associated with the rating of vendor services. To simplify the data, those respondents who rated vendor services as 1 or 2 ( very poor, poor) were considered dissatisfied. All others were considered satisfied.

Table 5 provides a number of results. Firstly, satisfaction in terms of vendor delivery of equipment appears to be associated with the rating of several curricular inclusions - Database and Spreadsheets, Information Analysis, Business Accounting Systems. In all cases, dissatisfaction with vendor provided services is associated with a lower rating of these curricular inclusions in terms of their importance.

Satisfaction with vendor provided information was examined to determine if it was associated with the rating of any of the 15 curricular inclusions. Table 5 shows that the rating of two curricular inclusions - Business Accounting Systems, Management Principles were associated with the level of satisfaction of the respondents. Those who were satisfied with vendor provided information rated the curricular inclusion Business Accounting Systems higher than those who expressed dissatisfaction. This was reversed for the curricular inclusion Management Principles, with those who were dissatisfied rating it higher than those who expressed satisfaction. The results in Table 5 show that the level of satisfaction with the equipment is associated with two curricular inclusions - DataBase and Spreadsheets, Information Analysis. In both cases those who were satisfied rated the curricular inclusions higher than those who were dissatisfied.

Satisfaction with after sales service is associated with the rating of one curricular inclusion - Statistics. Those who were satisfied with the after sales service rated this inclusion higher than those who were not. 
Table 5

The Rating of Potential Curricular Inclusions in a College/University IT Training Course for Small Business which were Associated with the Ratings of Vendor Services

\begin{tabular}{|c|c|c|c|c|c|c|c|}
\hline \multirow[t]{2}{*}{ Vendor Service } & \multirow[t]{2}{*}{$\begin{array}{l}\text { Subject } \\
\text { Servic }\end{array}$} & \multirow[t]{2}{*}{ Rating of } & \multicolumn{5}{|c|}{$\begin{array}{c}\text { Rating of Importance of Curricular } \\
\text { Inclusions }\end{array}$} \\
\hline & & & 1 & 2 & 3 & 4 & $\begin{array}{l}5 \\
\text { impt. }\end{array}$ \\
\hline \multirow[t]{6}{*}{ Delivery of Equipment } & \multirow{2}{*}{\multicolumn{2}{|c|}{ 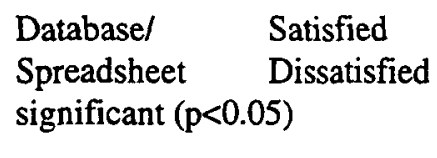 }} & 0 & 3 & 7 & 26 & 70 \\
\hline & & & 2 & 2 & 1 & 6 & 14 \\
\hline & \multirow{2}{*}{\multicolumn{2}{|c|}{$\begin{array}{l}\text { Information } \quad \text { Satisfied } \\
\text { Analysis } \\
\text { significant }(p<0.05)\end{array}$}} & 0 & 3 & 20 & 28 & 55 \\
\hline & & & 2 & 1 & 5 & 9 & 8 \\
\hline & Business Acct & Satisfied & 0 & 1 & 8 & 38 & 59 \\
\hline & $\begin{array}{l}\text { Systems } \\
\text { significant }(p<\end{array}$ & $\begin{array}{l}\text { Dissatisfied } \\
\text { D05) }\end{array}$ & 3 & 1 & 3 & 7 & 11 \\
\hline \multirow[t]{4}{*}{ Vendor Provided Info. } & \multirow{2}{*}{\multicolumn{2}{|c|}{$\begin{array}{l}\text { Business Acct. } \quad \text { Satisfied } \\
\text { Systems } \\
\text { significant }(p<0.05)\end{array}$}} & 2 & 0 & 11 & 29 & 58 \\
\hline & & & 1 & 2 & 1 & 13 & 14 \\
\hline & Management & Satisfied & 7 & 5 & 32 & 38 & 18 \\
\hline & $\begin{array}{l}\text { Principles } \\
\text { significant }(\mathrm{p}<\end{array}$ & $\begin{array}{l}\text { Dissatisfied } \\
05)\end{array}$ & 0 & 7 & 6 & 13 & 5 \\
\hline \multirow[t]{4}{*}{ Equipment } & \multirow{2}{*}{\multicolumn{2}{|c|}{$\begin{array}{l}\text { Database/ } \quad \text { Satisfied } \\
\text { Spreadsheet } \quad \text { Dissatisfied } \\
\text { significant }(p<0.005)\end{array}$}} & 0 & 6 & 8 & 28 & 71 \\
\hline & & & 2 & 0 & 0 & 4 & 12 \\
\hline & Information & Satisfied & 1 & 5 & 24 & 29 & 53 \\
\hline & $\begin{array}{l}\text { Analysis } \\
\text { significant }(\mathrm{p}<\end{array}$ & $\begin{array}{l}\text { Dissatisfied } \\
05)\end{array}$ & 2 & 0 & 1 & 8 & 7 \\
\hline \multirow[t]{2}{*}{ After Sales Service } & \multirow[t]{2}{*}{ Statistics } & Satisfied & 6 & 14 & 26 & 33 & 17 \\
\hline & & $\begin{array}{l}\text { Dissatisfied } \\
05 \text { ) }\end{array}$ & 6 & 7 & 15 & 4 & 3 \\
\hline \multirow[t]{2}{*}{ Training } & \multirow[t]{2}{*}{ Marketing } & Satisfied & 11 & 7 & 25 & 27 & 7 \\
\hline & & $\begin{array}{l}\text { Dissatisfied } \\
\text { 05) }\end{array}$ & 3 & 6 & 19 & 10 & 16 \\
\hline Manuals & \multicolumn{2}{|c|}{$\begin{array}{lc}\text { Statistics } & \text { Satisfied } \\
& \text { Dissatisfied } \\
\text { significant }(p<0.05)\end{array}$} & $\begin{array}{l}6 \\
6\end{array}$ & $\begin{array}{l}16 \\
6\end{array}$ & $\begin{array}{l}21 \\
21\end{array}$ & $\begin{array}{l}29 \\
7\end{array}$ & $\begin{array}{l}9 \\
10\end{array}$ \\
\hline
\end{tabular}

The results in Table 5 show that the level of satisfaction with vendor provided training is associated with the curricular inclusion Marketing. Unlike the rating of after sales service, those who rated the training as satisfactory tended to rate the inclusion Marketing lower than those who were dissatisfied.

Finally Satisfaction in terms of vendor provided manuals was compared to the 15 curricular inclusions. The results in Table 5 show that satisfaction with vendor provided manuals is associated with the rating of the inclusion Statistics. While those who were dissatisfied with the vendor provided service could see some merit in the inclusion, those who were satisfied, at best, tended to be equivocal concerning its importance. 


\section{DISCUSSION}

Before discussing the issues raised by the data and examining the hypotheses posited, the limitations of the study need to be emphasised. The first obvious limitation of this pilot study is the geographic spread of the respondent small businesses. All respondents were located in one urban region of Australia. All businesses are within easy commuting distance of a large university campus and a high percentage of managers have had some university experience. The second limitation of this study centres around the concepts of satisfaction and perception of importance. The literature suggests that very often these concepts are viewed comparatively rather than in their own right. For example, it may be argued that dissatisfaction with vendor provided training may be a measure of it being less effective than vendor supplied after sales service. Thus while training may have, of itself, been successful, it was judged comparatively with other measures. Finally, the comparison of curricular inclusions, rated across a five point scale and satisfaction rated across a two point scale does not necessarily provide a linear basis for discussion. The reduction, however, of satisfaction to a two point scale was deliberate such that comparative issues were reduced.

Despite the limitations, a number of insights are provided by the data. Firstly, there appears to be an overwhelming desire by the respondents for some form of university/college IT training program specifically directed towards small business. The study confirmed earlier findings by Cragg \& Zinatelli (1995) and Chen (1993), that computer technology in the small business arena is still primarily aimed at accounting type functions. This is highlighted in the data with accounting centred curricular inclusions being rated higher than other less accounting centred ones. Indeed, the data suggests that technical inclusions - Structure and Function of Hardware and Software and Programming are of little interest to the small business manager.

Of particular interest is the rating by respondents of vendor supplied services. It would seem that vendor companies are primarily sales directed and provide far better pre-sales service than their after sales. Vendor provided training and manuals appear to be inadequate to the need of the small business.

Two hypotheses were posited. The first suggested that satisfaction with vendor provided pre-sales service would be associated with a higher rating of those curricular inclusions deemed important. The results showed that three of the top inclusions - Database and Spreadsheets, Information Analysis, Business Accounting Systems were rated higher by those who expressed satisfaction as compared to those who expressed dissatisfaction. Interestingly, one inclusion not within the top six, Management Principles, was also associated with the level of satisfaction of vendor provided pre-sales service and actually showed a reversal of rating association, with those who were dissatisfied rating it higher than those who expressed satisfaction. As such, the first hypothesis is rejected.

A number of reasons for the associations are possible. It may be argued that those who rate inclusions such as Database and Spreadsheets, Information Analysis, Business Accounting Systems were better planned in their acquisition of IT. In such cases more attention was paid to vendor provided information, delivery schedules and actual equipment. Conversely it may be argued that satisfaction with the vendor has allowed the small business more scope to investigate training and training requirements than a less satisfied customer.

The second hypothesis suggested that higher levels of satisfaction with vendor provided post-sales service would be associated with higher ratings of those inclusions deemed less important. Unlike the studies carried out by MacGregor \& Cocks (1994), this study does not support the hypothesis. While it is true to say that post-sales satisfaction is only associated with the rating of less important inclusions, the nature of the association varies both with the particular vendor service as well as the inclusion.

\section{CONCLUSION}

This pilot study of 131 small businesses in Australia has examined both the perception of vendor services as well as the perception of training needs. The results suggest that there is an overwhelming need for the development of a university/college IT training program directed specifically towards small business. These programs should avoid the more technical aspects of IT and concentrate on areas which invlove the analysis and use of software in the small business.

The results further show that there is a perception by small business that vendor post-sales service, particularly in the areas of training and manuals are not adequate.

Finally the study has shown that a number of vendor provided services appear to be associated with the rating of importance of potential curricular inclusions in IT training programs.

Although the results have important implications, additional research is required in a number of areas. Firstly, the reasons why certain measures of satisfaction only appear to be associated with certain curricular inclusions. In order to pursue this, these factors need to be refined and followed up by extensive interviewing. Perhaps more importantly, a more intensive examination needs to be carried out to examine how small businesses communicate with vendors, such that the effect of various measures of satisfaction may be better explained. 


\section{REFERENCES}

Ang A.Y. (1992) Information Systems Curricula: A Southeast Asian Perspective Journal of Computer Information Systems pp. 7 - 15

Ang A.Y. \& Lo B.W.N. (1991) Changing emphasis in information systems curriculum: An Australian Industrial Perception Proceedings of the Second Conference on Information Systems and Database Special Interest Group pp. 339 - 355

Baker W.H. (1987) Status of Information Management in Small Businesses Journal of Systems Management vol 38 , No. 4, pp 10 - 15

Beeson G.W., Stokes D.M. \& Symmonds H.C. (1992) An Innovative Higher Education Course to Meet Industry's Needs Journal of Higher Education Research and Development vol 11, no. 1, pp 21 38

Bergeron F., Raymond L. \& Rivard S. (1992) Organisational Benefits of Electronic Data Interchange Proceedings of the Third Australian Conference on Information Systems Wollongong, Australia pp $563-578$

Brigham E.F. \& Smith K.V. (1967) The cost of capital to the small firm The Engineering Economist vol. 13, no. 1, pp. 1 - 26

Chan Y.E. \& Huff S.L. (1993) Investigating Information Systems Strategic Alignment Proceeding of the 14th Annual Conference on Information Systems Orlando, Fl, pp 345 - 363

Chen J.C. (1993) The impact of microcomputers on small businesses: England 10 years later Journal of Small Business Management vol. 31, no. 3, pp. 96 - 102

Cragg P.B. \& Zinatelli N. (1995) The Evolution of Information Systems in Small Firms Information \& Management vol 29, pp 1-8

Cragg P.B. \& King M. (1993) Small Firm Computing: Motivators and Inhibitors MIS Quarterly vol. 17, no. 1, pp. $47-60$

Dawkins J.S. (1988) Higher Education: A Policy Statement Canberra, Australian Government Printing Office

Delone W.H. (1988) Determinants for Success for Computer Usage in Small Business MIS Quarterly pp. 51 61

DelVecchio M. (1994) Retooling the Staff along with the system Bests Review vol. 94, no. 11, pp. $82-83$

El-Khawas E. (1985) Campuses Weld the Corporate Link Educational Record Spring pp 37 - 39

Hansen L.A. (1985) A More or Less Happy Relationship: Industry University Co-Operation in Denmark European Journal of Education 10, pp 197 - 208

Hedberg J \& Harper B. (1992) Information Systems Strategy in the Small Education Organisation Proceedings of the Third Australian Conference on Information Systems Wollongong, Australia

Heikkila J., Saarinen T. \& Saaksjarvi M. (1991) Success of Software Packages in Small Business: An Exploratory Study European Journal of Information Systems Vol 1, No. 3, pp 159 - 169

Holzinger A.G. \& Hotch R. (1993) Small Firms Usage Patterns Nations Business vol. 81, no. 8, pp. 39 - 42

Kahn H. \& Robertson I.T. (1992) Training and Experience as Predictors of Job Satisfaction and Work Motivation When Using Computers Journal of Behaviour and Information Technology vol. 11, pp $53-60$

Lo B.W.N. (1991) Australian Information Systems Curricula The Journal of Computer Information Systems vol. 31 , pp. $20-33$

MacGregor R.C. \& Clarke R.J. (1988) The Loss of the 'Informal' in Systems Design in Bullinger H.J., Protonotarios E.N., Bouwhuis D. \& Relm F. (eds.) Proceedings of Eurinfo '88 Athens, Greece

MacGregor R.C. \& Cocks R.S. (1994) Computer Usage and Satisfaction in the Australian Veterinary Industry Australian Veterinary Practitioner vol 25 no 1 pp 43 - 48

MacGregor R.C. \& Bunker D.J. (1997) The Effect of Criteria Used in the Acquisition of Computer Technology on the Ongoing Success with Information Technology in Small Business, forthcoming

MacGregor R.C., Bunker D.J., Cocks R.S., Pierson J.K. \& Forcht K.A. (1997) A Comparison of Two Studies Examining Computer Education Requirements in Small Business, forthcoming

Meredith G.G. (1994) Small Business Management in Australia McGraw Hill, 4th Edition

Neergaard P. (1992) Microcomputers in Small and Medium Sized Companies: Benefits Achieved and Problems Encountered Proceedings of the Third Australian Conference on Information Systems Wollongong, Australia

Nelson R.R. (1991) Education Needs as Perceived by IS and End-User Personnel: A Survey of Knowledge and Skill Requirements MIS Quarterly December pp 503 - 521 
Raymond L. (1988) The Impact of Computer Training on Attitudes and Usage Behaviour of Small Business Managers Journal of Small Business Management vol. 26, pp. 8 - 13

Raymond L. (1990) End User Computing in the Small Business Context: Foundations and Directions for Research Data Base vol 20, no. 3, pp 20 - 28

Raymond L. \& Paré G. (1992) Measurement of Information Technology Sophistication in Small Manufacturing Businesses Information Resource Management Journal vol 5, no. 2, pp 1- 13

Raymond L. \& Bergeron F. (1992) Personal DSS Success in Small Enterprises Information \& Management vol 22, no. 5, pp $301-308$

Raymond L., Paré G. \& Bergeron F. (1993) Information Technology and Organisational Structure Revisited: Implications for Performance Proceeding of the 14th Annual Conference on Information Systems Orlando, Fl, pp 129 - 143

Reynolds W., Savage W. \& Williams A. (1994) Your Own Business: A Practical Guide to Success ITP

Rislov S. (1979) Speaking with Employers in Cohen A.M. (ed.) Shaping the Curriculum Josey Bass, San Francisco, pp 51 - 54

Rotch W. (1967) Management of Small Enterprises: Cases and Readings University of Virginia Press

Seeborg I.S. \& Ma C. (1989) MIS Program Meets Reality: A Survey of Alumni from an Undergraduate Program Interface vol. 10, pp. 51 - 60

Sharp C. \& Lewis N. (1992) Corporate Memory and Management Information Systems Proceedings of the Third Australian Conference on Information Systems Wollongong, pp 149 - 160

Turner J.A. \& Karasek R.A. jr (1984) Software Ergonomics: Effects of Computer Application Design Parameters on Operator Task Performance and Health Ergonomics vol. 27, no. 6, pp 663 - 690

Walker E.W. (1975) Investment and Capital Structure Decision Making in Small Business in Walker E.W. (ed.) The Dynamic Small Firm: Selected Readings Austin Press, Texas

Wattenberger J.I \& Scaggs (1979) Curriculum Revision and the Process of Change in Cohen A.M. (ed.) Shaping the Curriculum Josey Bass, San Francisco, pp $1-10$

Williams T.A. (1992) Information Technology and Interorganisation Change Proceedings of the Third Australian Conference on Information Systems Wollongong, Australia pp 295 - 308

Yap C.S., Soh C.P.P. \& Raman K.S. (1992) Information Systems Success Factors in Small Business International Journal of Management Science 20, pp. 597 - 609 